\title{
Analisis Sifat Fisik Velva Labu Kuning dengan Kombinasi Pektin dan Gum Arab Sebagai Bahan Penstabil
}

\author{
Eriska Yuriska Indriya Priyono Dewi, Soenar Soekopitodjo, Issutarti \\ Universitas Negeri Malang, Jl. Semarang No. 5 Malang, Jawa Timur, Indonesia \\ *Penulis korespondensi, Surel: soenar.soekopitojo.ft@um.ac.id
}

Paper received: 05-02-2021; revised: 18-02-2021; accepted: 30-02-2021

\begin{abstract}
Abstrak
Labu kuning kaya akan kandungan $\beta$-karoten, serat pangan dan vitamin $\mathrm{C}$ yang tinggi. Labu kuning memungkinkan untuk dijadikan velva yang merupakan produk sejenis es krim yang terbuat dari bahan utama buah atau sayuran. Keunggulan produk velva yaitu memiliki kandungan serat yang tinggi dan rendah lemak. Penelitian ini bertujuan untuk mengetahui pengaruh penggunaan kombinasi pektin dan gum arab sebagai bahan penstabil terhadap sifat fisik (overrun dan daya leleh) velva labu kuning. Jenis penelitian yang digunakan termasuk dalam penelitian eksperimen dengan menggunakan metode Rancangan Acak Lengkap (RAL), yang terdiri dari satu faktor dengan tiga tingkatan. Perlakuan pada penelitian ini dengan penambahan bahan penstabil pektin dan gum arab dengan rasio 67\%:33\%, 50\%:50\%. 33\%:67\%. Pada masing-masing perlakuan dilakukan dua kali pengulangan. Data dianalisis menggunakan ANOVA apabila terdapat perbedaan maka, akan dilakukan uji lanjut dengan uji Duncan's Multiple Range Test (DMRT) dengan signifikansi 5\%. Data hasil analisis penelitian menunjukkan terdapat perbedaan nyata pada masing-masing perlakuan dengan rasio yang berbeda. Nilai tertinggi sifat fisik (overrun dan daya leleh) diperoleh dari kombinasi pektin dan gum arab dengan rasio 33\%:67\%. Hasil dari penelitian menunjukkan sifat fisik overrun velva labu kuning memperoleh rerata $35,714 \%$, sifat fisik daya leleh velva labu kuning memperoleh rerata 59,292 menit.
\end{abstract}

Kata kunci: velva labu kuning; pektin; gum arab; overrun; daya leleh

\section{Pendahuluan}

Labu kuning (Cucurbita moschata Durch.) merupakan bahan pangan yang banyak mengandung $\beta$-karoten atau provitamin $A$, zat gizi seperti protein, karbohidrat, beberapa mineral seperti kalsium, fosfor, besi, serta beberapa vitamin yaitu vitamin B dan C (Hendrasty, 2003). Menurut Ranonto, dkk. (2015), bahwa labu kuning memiliki warna daging buah yang menarik, keunggulan warna tersebut dapat dijadikan daya tarik bagi konsumen. Ketersediaan labu kuning yang melimpah tidak diimbangi dengan pemanfaatan menjadi produk yang lebih inovatif dan kreatif. Menurut Santoso, dkk. (2013), labu kuning cukup potensial sebagai bahan dasar industri maupun bahan industri jasa boga.

Velva tergolong sebagai hidangan penutup atau salah satu jenis makanan beku, sejenis dengan es krim akan tetapi, berkadar lemak rendah karena tidak menggunakan lemak susu (Sholihah,dkk., 2017). Menurut Desi, dkk. (2014), bahwa kelebihan velva yaitu mengandung vitamin $\mathrm{C}$ dan serat pangan yang tinggi.

Syarat lain velva dalam kategori yang baik, yaitu velva dengan daya leleh lama dan overrun tinggi. Velva buah yang baik apabila, memiliki tekstur lembut, halus dan memiliki kecepatan leleh rendah (Mardianti, 2016). Kecepatan leleh velva dipengaruhi oleh bahan penstabil. Velva tanpa bahan penstabil akan menghasilkan velva dengan tekstur kurang baik, karena kristal es terlalu banyak dan besar yang menyebabkan velva mudah meleleh (Basito, dkk., 2018). Nilai overrun menurut Sapriyanti, dkk. (2014), merupakan persentase rasio pengembangan volume produk. Overrun yang lebih tinggi menandakan ada lebih banyak sel- 
sel volume es krim, volume udara yang lebih besar karena, celah lamelar antara gelembung udara yang lebih besar (Goff dan Hartel, 2013). Overrun dihitung berdasarkan perbedaan volume es krim dan volume ICM yang dinyatakan dalam persen (Susilorini \& Sawitri, 2006). Overrun terbentuk pengadukan saat proses pendinginan dalam ice cream maker, tanpa adanya overrun maka velva akan berbentuk gumpalan massa yang keras yang menyebabkan tekstur yang kasar.

\section{Metode}

\subsection{Rancangan Penelitian}

Penelitian yang dilakukan merupakan penelitian eksperimen, dengan metode rancangan acak lengkap (RAL), satu faktor dengan tiga tingkatan yang berbeda. Perlakuan penelitian ini penggunaan bahan penstabil pektin dan gum arab yang digunakan pada velva labu kuning, yaitu (33\%:67\%), (50\%:50\%) dan (67:33\%), masing-masing perlakuan diulang sebanyak dua kali. Pengamatan dilakukan terhadap sifat fisik overrun dan daya leleh velva labu kuning. Metode yang digunakan pada analisis sifat fisik overrun dengan mass and volume measurement, sifat fisik daya leleh dianalisis dengan melting time measurement. Bahan baku dalam penelitian velva labu kuning ini terdiri dari puree labu kuning, air, gula, asam sitrat, bahan penstabil yaitu pektin dan gum arab.

Tabel 1. Bahan Pembuatan Velva Labu Kuning

\begin{tabular}{|c|c|c|c|c|}
\hline No & $\begin{array}{l}\text { Nama } \\
\text { Bahan }\end{array}$ & $\begin{array}{l}\text { Formula } 1 \\
\text { (pektin:gum arab, } \\
67 \%: 33 \% \text { ) }\end{array}$ & $\begin{array}{l}\text { Formula II } \\
\text { (pektin:gum arab, } \\
\text { 50\%:50\%) }\end{array}$ & $\begin{array}{l}\text { Formula III } \\
\text { (pektin:gum arab, } \\
33 \%: 67 \% \text { ) }\end{array}$ \\
\hline 1 & $\begin{array}{l}\text { Labu } \\
\text { Kuning }\end{array}$ & $250 \mathrm{~g}$ & $250 \mathrm{~g}$ & $250 \mathrm{~g}$ \\
\hline 2 & Air & $250 \mathrm{ml}$ & $250 \mathrm{ml}$ & $250 \mathrm{ml}$ \\
\hline 3 & Gula & $50 \mathrm{~g}$ & $50 \mathrm{~g}$ & $50 \mathrm{~g}$ \\
\hline 4 & Asam Sitrat & $0,5 \mathrm{~g}$ & $0,5 \mathrm{~g}$ & $0,5 \mathrm{~g}$ \\
\hline 5 & Pektin & $2,5 \mathrm{~g}$ & $1,875 \mathrm{~g}$ & $1,25 \mathrm{~g}$ \\
\hline 6 & Gum Arab & $1,25 \mathrm{~g}$ & $1,875 \mathrm{~g}$ & $2,5 \mathrm{~g}$ \\
\hline
\end{tabular}

\subsection{Data Penelitian}

Pada produk velva labu kuning dengan penggunaan pektin dan gum arab sebagai bahan penstabil dengan rasio 67\%:33\%, 50\%:50\%. 33\%:67\%., dilakukan penelitian yang mencakup sifat fisik yang terdiri dari overrun dan daya leleh.

\subsection{Analisis Data Penelitian}

Analisis dilakukan pada data uji fisik (overrun dan daya leleh). Data dianalisis dengan metode ANOVA dengan taraf signifikansi 5\%. Apabila data terdapat perbedaan yang nyata pada taraf signifikansi $\mathrm{p}<0,005$ maka, akan dilakukan dengan uji lanjut DMRT (Duncan's Multiple Range Test). Panelis yang dilibatkan pada uji hedonik (kesukaan) yaitu panelis agak terlatih sebanyak 35 orang yang dilakukan dengan dua kali pengulangan. 


\section{Hasil dan Pembahasan}

\subsection{Sifat Fisik}

\subsection{Overrun}

\section{Tabel 2. Rerata Sifat Fisik Overrun Velva Labu Kuning Kombinasi Bahan Penstabil} Pektin dan Gum Arab

\begin{tabular}{ccccc}
\hline \multirow{2}{*}{ Sampel } & \multicolumn{2}{c}{ Overrun (\%) } & Total & Rerata \\
\cline { 2 - 5 } & $\mathbf{1}$ & $\mathbf{2}$ & & \\
\hline $67 \%: 33 \%$ & 19,048 & 18,182 & 37,230 & 18,615 \\
$50 \%: 50 \%$ & 30,000 & 28,571 & 58,571 & 29,286 \\
$33 \%: 67 \%$ & 28,095 & 33,333 & 71,428 & 35,714 \\
\hline
\end{tabular}

Berdasarkan hasil yang ditunjukkan pada Tabel 2, rerata kandungan overrun velva labu kuning 67\%:33\% yaitu 18,615\%, 50\%:50\% yaitu 29,286\%, 33\%:67\% yaitu 35,714\%. Hasil analisis velva labu kuning dengan rasio pektin dan gum arab (67\%:33\%), (50\%:50\%), (33\%:67\%) memiliki sifat fisik overrun yang berbeda. Overrun tertinggi dengan rerata 35,714\% diperoleh dari bahan penstabil pektin dan gum arab dengan rasio 33\%:67\%., sedangkan overrun terendah dengan rerata $18,615 \%$, diperoleh dari bahan penstabil pektin dan gum arab dengan rasio 67\%:33\%. Penggunaan bahan penstabil dengan rasio gum arab yang semakin banyak, mengakibatkan nilai overrun akan semakin tinggi, begitu juga sebaliknya semakin sedikit persentase gum arab yang digunakan pada velva labu kuning akan mengakibatkan nilai overrun velva semakin rendah.

Hal ini disebabkan besarnya overrun_suatu sampel ditentukan oleh bahan penstabil gum arab. Gum arab memiliki memiliki sifat mudah larut dalam air dibandingkan dengan jenis hidrokoloid yang lainnya (Setyawan, 2007), sehingga overrun velva tinggi. Gum arab termasuk dalam polisakarida yang memiliki karakteristik yang sangat baik yaitu viskositas yang relatif rendah dengan sifat menstabilkan dan mengemulsi (Taylor dan Fancis, 2006). Menurut Djajati, dkk. (2017), adonan yang semakin kental yang disebabkan banyaknya padatan, akan mengalami kesulitan untuk mengembang karena udara sulit untuk menembus masuk permukaan adonan.

\subsection{Daya Leleh}

Tabel 3. Rerata Sifat Fisik Daya Leleh Velva Labu Kuning Kombinasi Bahan Penstabil Pektin dan Gum Arab

\begin{tabular}{ccccc}
\hline \multirow{2}{*}{ Sampel } & \multicolumn{2}{c}{ Rerata Daya Leleh (menit) } & Total & Rerata \\
\cline { 2 - 5 } & $\mathbf{1}$ & $\mathbf{2}$ & \\
\hline $67 \%: 33 \%$ & 38,266 & 42,383 & 80,649 & 40,325 \\
$50 \%: 50 \%$ & 51,416 & 55,366 & 106,782 & 53,391 \\
$33 \%: 67 \%$ & 58,450 & 60,133 & 118,583 & 59,292 \\
\hline
\end{tabular}

Berdasarkan hasil yang ditunjukkan pada Tabel 3, rerata kandungan daya leleh velva labu kuning 67\%:33\% yaitu 40,325 menit, 50\%:50\% yaitu 53,391 menit, 33\%:67\% yaitu 59,292 menit. Hasil analisis velva labu kuning dengan rasio pektin dan gum arab (67\%:33\%), 
(50\%:50\%), (33\%:67\%) memiliki sifat fisik daya leleh yang berbeda. Daya leleh tertinggi dengan rerata 59,292 menit diperoleh dari bahan penstabil pektin dan gum arab rasio 33\%:67\%, sedangkan daya leleh terendah dengan rerata 40,325 menit diperoleh dari bahan penstabil pektin dan gum arab dengan rasio 67\%:33\%. Penggunaan bahan penstabil dengan rasio gum arab yang semakin banyak, mengakibatkan nilai daya leleh akan semakin tinggi, begitu juga sebaliknya semakin sedikit rasio gum arab yang digunakan pada velva labu kuning akan mengakibatkan nilai daya leleh velva semakin rendah.

Hal ini disebabkan daya leleh yang lama pada suatu sampel disebabkan oleh bahan penstabil gum arab. Kemampuan gum arab dalam mengikat air cukup baik dapat mencegah terjadinya pembentukan kristal es yang besar sehingga dapat meningkatkan daya tahan terhadap pelelehan (Susilowati, dkk., 2013). Sofjan dan Hartel (2004), overrun yang baik dan tinggi mampu mengurangi kemampuan panas untuk menembus es krim sehingga, es krim tidak mudah meleleh. Hal ini diduga pada produk rendah lemak ini menggunakan bahan penstabil pektin dan gum arab yang berperan sebagai stabilisator.

Kecepatan leleh velva dipengaruhi oleh bahan penstabil, apabila velva tanpa bahan penstabil akan menghasilkan velva dengan tekstur kurang baik, karena kristal es terlalu banyak dan besar sehingga velva mudah meleleh (Basito, dkk., 2018). Goff dan Hartel (2013) gum arab sebagai stabilisator dapat menghasilkan produk es krim yang lembut, mengurangi kristal es dan menghasilkan produk yang tidak cepat meleleh. Menurut Goff dan Hartel (2013), bahwa stabilisator diperlukan untuk peningkatan viskositas dan daya terima mulut, penggunaan stabilisator es krim bertujuan untuk meningkatkan viskositas campuran, mencegah penyusutan volume produk dan untuk mempertahankan produk terhadap peleburan. terjadinya pembentukan kristal es yang besar sehingga dapat meningkatkan daya tahan terhadap pelelehan (Susilowati, dkk., 2013).

\section{Simpulan}

Perlakuan penggunaan kombinasi bahan penstabil pektin dan gum arab menunjukkan terdapat perbedaan nyata terhadap sifat fisik overrun dan daya leleh velva labu kuning. Sifat fisik overrun velva labu kuning tertinggi diperoleh dari kombinasi bahan penstabil pektin dan gum arab dari rasio 33\%:67\% memiliki rerata 35,714\%. Sifat fisik daya leleh velva labu kuning tertinggi diperoleh dari kombinasi bahan penstabil pektin dan gum arab dari rasio 33\%:67\%, memiliki rerata 59,292 menit.

\section{Daftar Rujukan}

Goff H. D., \& Hartel R. W. 2013. Ice Cream. Department of Food Science. New York Heldelberg Dordrecht London.

Hendrasty, H. K. (2003). Tepung Labu Kuning Pembuatan dan Pemanfatannya. Yogyakarta: Kanisus.

Mardianti, A., Praptiningsih, Y., \& Kuswardhani, N. (2016). Karakteristik velva buah mangga endhog (Mangifera indica L.) dengan penstabil CMC dan pektin.

Ranonto, N. R., Nurhaeni, N., \& Razak, A. R. (2015). Retensi karoten dalam berbagai produk olahan labu kuning (Cucurbita moschata Durch). Natural Science: Journal of Science and Technology, 4(1).

Sakawulan, D., Budi, F. S., \& Syamsir, E. (2014). Pembuatan velva fruit pisang dengan bahan dasar tepung pisang dan carboxy methyl cellulose sebagai bahan penstabil. Jurnal Aplikasi Teknologi Pangan, 3(4).

Sapriyanti, R., Nurhartadi, E., \& Ishartani, D. (2014). Karakteristik Fisikokimia dan Sensori Velva Tomat (Lycopersicum esculentum Mill) dengan Pemanis Madu. Jurnal Teknologi Hasil Pertanian, 7(1).

Setyawan, A. (2007). Gum Arab. 
Jurnal Inovasi Teknik dan Edukasi Teknologi, 1(2), 2021, 137-141

Sholihah, R., Yusmarini, Y., \& Johan, V. S. Pemanfaatan Bubur Nanas dalam Pembuatanvelva Ubi Jalar Ungu (Doctoral dissertation, Riau University).

Sofjan, R. P., \& Hartel, R. W. (2004). Effects of overrun on structural and physical characteristics of ice cream. International Dairy Journal, 14(3), 255-262.

Susilowati, T., \& Candra, D. A. (2013). Pembuatan velva sayuran (kajian proporsi wortel, tomat, kecambah dan penambahan na-cmc terhadap kualitas velva sayuran). Jurnal Teknologi Pangan, 4(2).

Stephen, A. M., \& Phillips, G. O. (2016). Food polysaccharides and their applications. CRC press. 